\title{
AN EXPERIMENTAL STUDY TO DETERMINE THE COMPACTION \\ CHARACTERISTICS AND CALIFORNIA BEARING RATIO OF \\ SOIL MIXED WITH FLY ASH AND DISCRETE FIBRE
}

\author{
P. LAVANYA REKHA, VINAY ANAND. D \& P. VEENA \\ Assistant Professor, Vignan Institute of Information Technology (Autonomous), \\ Duvvada, Visakhapatnam, Andhra Pradesh, India
}

\begin{abstract}
Expansive soils have the ability to swell and shrink, which causes lots of structural damages. In the present scenario, soil is stabilized using different waste materials in order to improve its strength. In this study, fly ash and fibers were mixed with soil to investigate the relative strength gain in terms of California bearing ratio tests. The effect of fly ash and fibre on geotechnical characteristics of soil - fly ash and soil-fly ash-fibre mixtures was investigated by conducting standard proctor compaction tests, CBR tests. The tests were performed as per Indian standard specifications. The soil used for the study was brought from Doultabad of Medak district. The physical properties of the soil were determined as per IS specifications. Fly ash for the study was brought from Raichur, Karnataka. An experimental study was carried out to determine the compaction characteristics and California bearing ratio of soil and fly ash mixed with discrete fibre of $12 \mathrm{~mm}$ length. The results obtained from the study indicate that the addition of fly ash and fibre to soil increases the California bearing ratio values when compared to that of unreinforced soil.

KEYWORDS: Fly ash, Fiber, Compaction \& California Bearing Ratio
\end{abstract}

Received: Apr 11, 2019; Accepted: May 02, 2019; Published: Jun 13, 2019; Paper Id.: IJMPERDJUN2019182

\section{INTRODUCTION}

In pavements, Sub-grade is the most important element which is compacted before construction of road or railway track. The sub-grade must be able to support the loads transmitted from the pavement structure. This load bearing capacity is affected by moisture content, degree of compaction and type of soil

A sub grade, which supports huge amount of loads without undergoing any deformations, is considered to be good. As expansive soils are weak in strength and have the ability to swell and shrink in various parts of the world there is every need to improve the strength by reinforcing the soil.

\section{BACKGROUND}

Stabilization of soils using different admixtures is a technique used since primitive ages. Many researchers have used fly ash and polypropylene fibers as a reinforcing material for the stabilization of soil.

Sharma. R. K. (2012) have determined the behavior of expansive soil mixed with fly ash and Recron 3S fibre. The properties like grain size distribution, moisture density relation and CBR are studied for soil mixed with fly ash in the range of $20-80 \%$. The mixture of soil with $30 \%$ fly ash has been selected for further modification with fibre content. The CBR of various soil samples were determined under soaked and unsoaked conditions. 
Mamta Mishra, Maheshwari. U. K., and Saxena. N. K. (2016) have conducted various tests on soil in order to improve the strength of weak soil using fly ash and fiber, due to which the load bearing capacity of soil can be improved and further it can be used for pavements and other road construction works.

Pooja Upadhyay, Kshama Singh(2018) used FLY ASH AND COIR FIBER as reinforcing materials for stabilization of soil due to which the strength of soil has improved and strong sub grades were formed without any deformations.

Kuldeep Singh Chouhan, Rajesh Jain. (2015) have determined the Effect of FlyAsh and Fibre on Index Properties of Black Cotton Soil

Sowmya Ratna. P., Prasad. D. S. V., Prasada Raju. G. V. R. (2016) have determined the Performance of Recron3s Fiber with Lime in Expansive Soil Stabilization

\section{MATERIALS AND METHODS}

\section{Materials}

The locally available soil is reinforced using fly ash and fibers. In which, fly ash is a waste material obtained by burning of coal in thermal power plants. The present fly ash used in the study was bought from Raichur, Karnataka. This material when added to soil will improve the strength of soil. Polypropylene fiber is a geo synthetic material. It is mainly used as reinforcing material in sub bases or sub soils below pavements. They are available in lengths of $6 \mathrm{~mm}$, $12 \mathrm{~mm}$ and $24 \mathrm{~mm}$. The fiber reinforcement causes significant improvement in tensile strength, shear strength, bearing capacity and other property as well as economy.
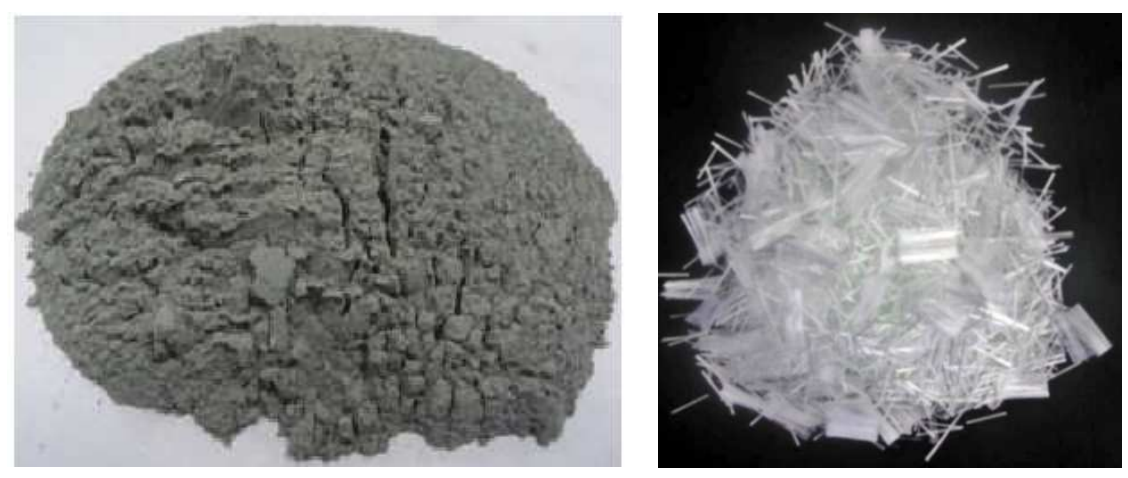

Figure 1: Fly Ash Polypropylene Fibers

The locally available soil is taken for testing purposes. The particle size distribution of the soil was determined by sieve analysis as per IS 2720 .

Table 1: Properties of the Soil used for the Study

\begin{tabular}{|l|c|}
\hline \multicolumn{1}{|c|}{ Sample Area } & Doultabad \\
\hline Gravel & 0 \\
\hline Sand & 44.12 \\
\hline Fines & 55.88 \\
\hline Liquid limit & $43 \%$ \\
\hline Plastic limit & $29 \%$ \\
\hline Specific gravity & 2.63 \\
\hline Differential Free Swell & $75 \%$ (Very High) \\
\hline
\end{tabular}




\section{and California Bearing Ratio of Soil Mixed With}

Fly Ash and Discrete Fibre

Various tests were performed in order to characterize the soil and the properties are given in Table 1. The soil has about around $55 \%$ fines, Liquid limit of $43 \%$, Plastic limit of $29 \%$, Specific gravity of 2.63 and a differential free swell of $75 \%$, making the clay a highly compressible clay which is denoted by $\mathrm{CH}$. Compaction tests are conducted to determine the amount of compaction and water content required in the field. The water content at which the maximum dry density is attained is obtained from the relationships provided by the tests. A compaction curve is plotted between the water content as basic and corresponding dry density as ordinate. The optimum water content of $21 \%$ and the maximum dry density of $1.46 \mathrm{~g} / \mathrm{cc}$ are used from the compaction curve of Figure 2.

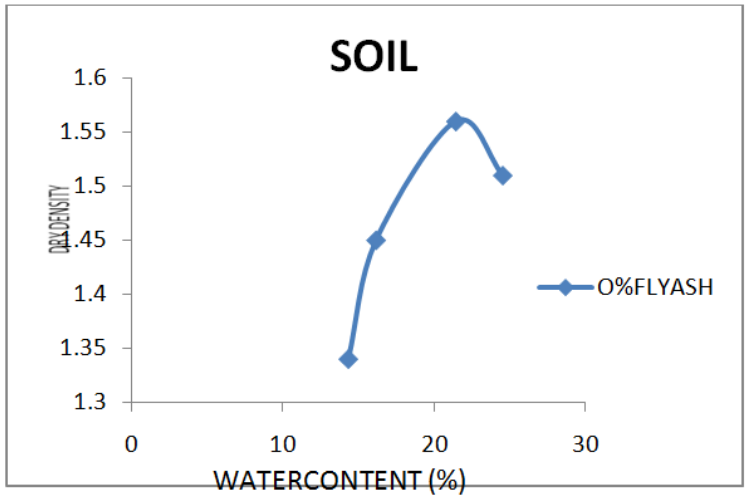

Figure 2: Compaction Curve of Unreinforced Soil

\section{Test Setup and Testing Methodology}

\section{Test Set Up}

For testing the material, the CBR test set up having a load frame of capacity $50 \mathrm{kN}$ is used. It has a plunger diameter of $50 \mathrm{~mm}$. The plunger in the CBR test penetrates the specimen in the mould at the rate of $1.25 \mathrm{~mm}$ per minute. The loads required for the penetration of $2.5 \mathrm{~mm}$ and $5.0 \mathrm{~mm}$ are determined. The penetration load is expressed as a percentage of the standard loads at the respective penetration level of $2.5 \mathrm{~mm}$ or $5.0 \mathrm{~mm}$.

The load-Penetration curve is plotted and then the corrected loads, after zero correction, corresponding to penetration of $2.5 \mathrm{~mm}$ and $5.0 \mathrm{~mm}$ are determined. The loads required for the penetration of $2.5 \mathrm{~mm}$ and $5.0 \mathrm{~mm}$ are determined. The penetration load is expressed as a percentage of the standard loads at the respective penetration level of $2.5 \mathrm{~mm}$ or $5.0 \mathrm{~mm}$. The CBR value is determined corresponding to penetration of $2.5 \mathrm{~mm}$ and $5.0 \mathrm{~mm}$.

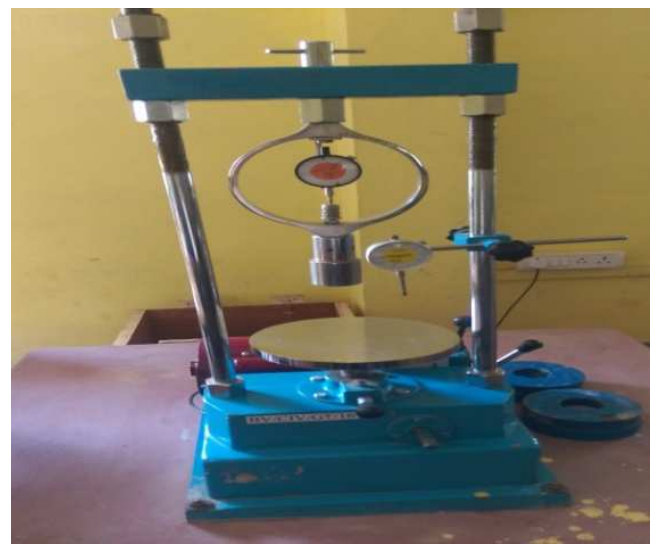

Figure 3: CBR Experimental Set up 


\section{Methodology}

The laboratory tests were carried out in two stages

- Reinforcement of soil with fly ash by varying percentage of $10 \%, 20 \%, 30 \%, 40 \%$ and $50 \%$.

- $\quad$ Reinforcement of soil with $20 \%$ fly ash and varying fibre content in percentages of $0.5 \%, 1.0 \%, 1.5 \%$.

Tests were conducted as per Indian Standards. In the first stage of process IS light compaction tests were conducted for soil blended with flyash of varying percentages i. e. $0 \%, 10 \%, 20 \%, 30 \%, 40 \%, 50 \%$, and from the test the optimum moisture content and dry density were determined. The optimum moisture content obtained from the test is used for conducting CBR for soil blended with flyash in percentages of $0 \%, 10 \%, 20 \%, 30 \%, 40 \%$, and $50 \%$.

In the second stage of investigation, the effect of fibre content on the soil blended with $20 \%$ fly ash is determined by conducting Compaction tests and CBR. The fiber was added in percentages of $0.5 \%, 1.0 \%, 1.5 \%$.

\section{RESULTS AND DISCUSSIONS}

\section{Effect of Fly Ash and Fiber on Compaction Characteristics of Soil}

IS light Compaction tests were conducted on soil mixed with varying proportions of 0\%, $10 \% 20 \% 30 \% 40 \%$ and $50 \%$. The test is conducted as per IS: 2720, Geotechnical engineering laboratory code. As per IS recommendations, the test consist of a mould of $1000 \mathrm{ml}$ capacity, and a $2.6 \mathrm{~kg}$ rammer falling from a height of $310 \mathrm{~mm}$.

The test was conducted by compacting the sample in 3 layers, where each layer was given 25 blows using $2.6 \mathrm{~kg}$ rammer at varying water contents. By performing the tests, the optimum moisture content and maximum dry density of $0 \%, 10 \%, 20 \%, 30 \%, 40 \%$ and $50 \%$ flyash blended with soil were determined. It was observed that the maximum dry density of soil initially increases and then starts reducing. The MDD was found to be maximum for $80 \%$ soil and $20 \%$ fly ash proportion. Figure 4 shows the variation of MDD with fly ash content.

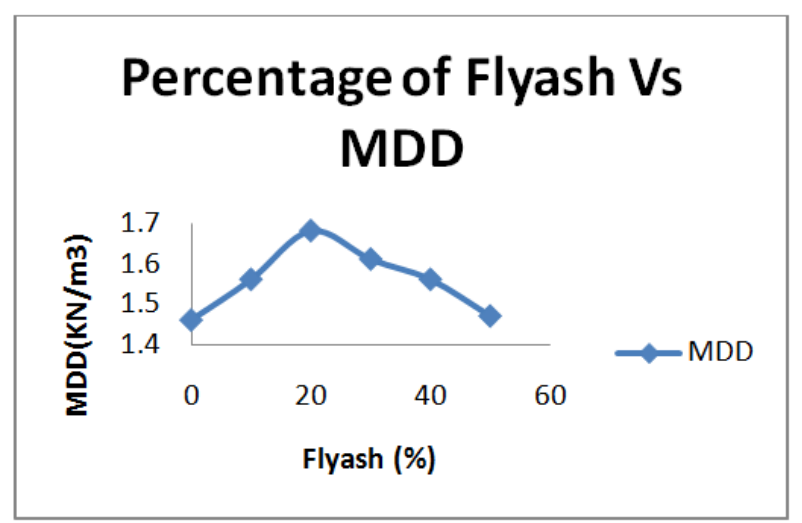

Figure 4: Variation of MDD with Fly Ash

And to this proportion of soil blended with $20 \%$ fly ash, fiber content is added in percentages of $0.5 \%$, $1.0 \%$, $1.5 \%$ and compaction tests were conducted. From the tests, it was observed that the maximum dry density of soil- fly ash mixed with fiber initially increases till $1.0 \%$, after which it decreases. For $1.0 \%$ fiber content in the blend of soil with $20 \%$ fly ash, the MDD value was found to be maximum Figure 5 shows the variation in MDD with fibre content. 


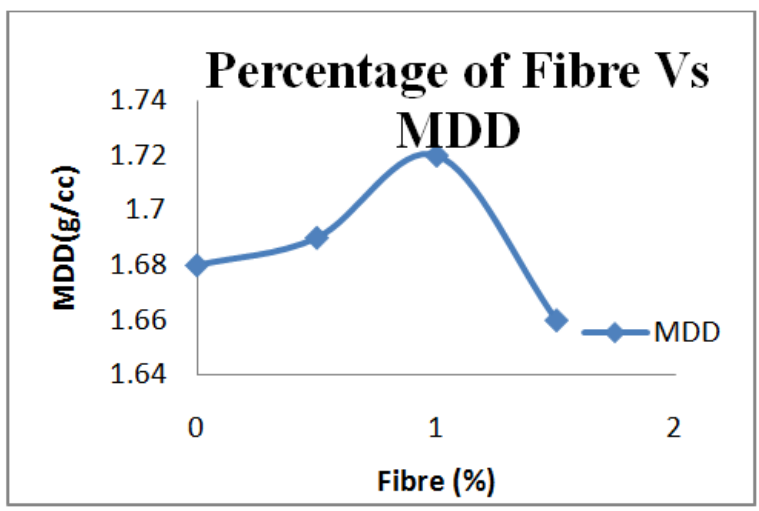

Figure 5: Variation of MDD with Fiber Content

\section{Effect of Fly Ash and Fiber on Strength Characteristics of Soil}

California Bearing Ratio tests (CBR) were conducted on soil mixed with flyash in varying percentages. The CBR samples was compacted to its OMC and MDD, which were obtained from IS light compaction tests. The CBR samples were tested in soaked conditions. It was observed from the study that CBR value initially increases and then starts decreasing. The maximum value of CBR was obtained for $80 \%$ Soil and $20 \%$ fly ash. Figure 6 shows the variation of CBR with varying percentages of fly ash in soil.

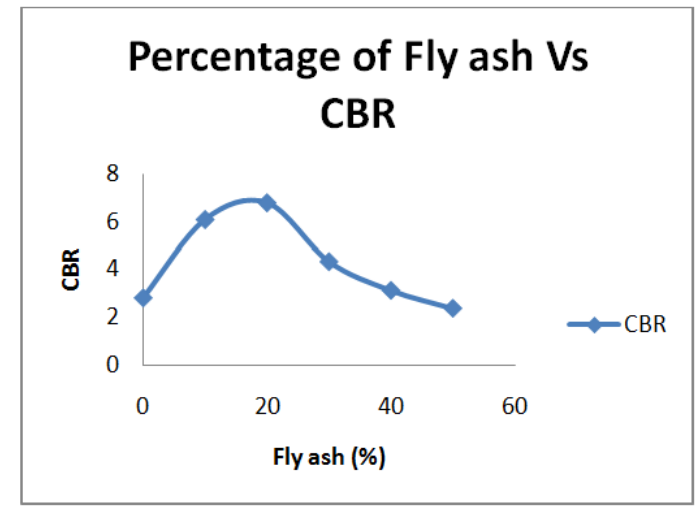

Figure 6: Variation of CBR with Fly Ash

Further, CBR tests were conducted on $80 \%$ soil-20\% Fly ash mix blended with varying percentages of fiber. From the tests, it was found that the CBR value initially increases till 1.0\% fiber and then starts decreasing. The maximum CBR value was found to be for fibre content of $1.0 \%$ in the blend of soil with $20 \%$ fly ash. The variation in CBR with fiber is shown in figure 7. 


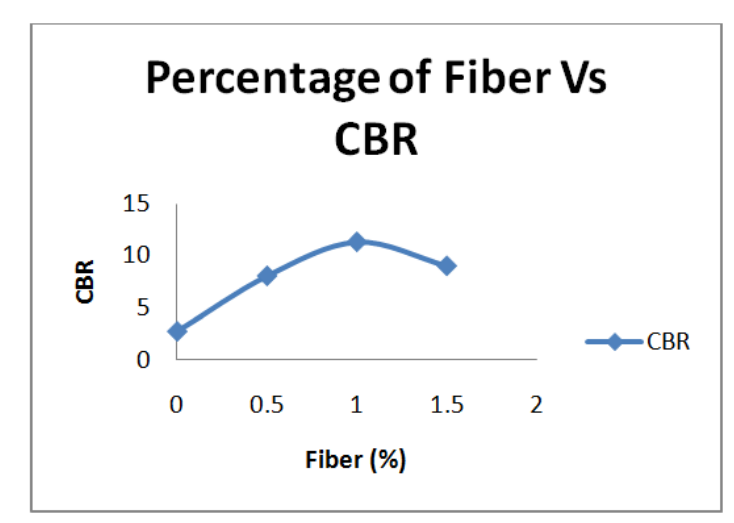

Figure 7: Variation in CBR with Fiber

The comparisons of CBR graphs i. e., load Vs penetration for unreinforced soil, soil reinforced with $20 \%$ fly ash and soil with $20 \%$ fly ash blended with $1.0 \%$ fiber were shown in Figure 8.

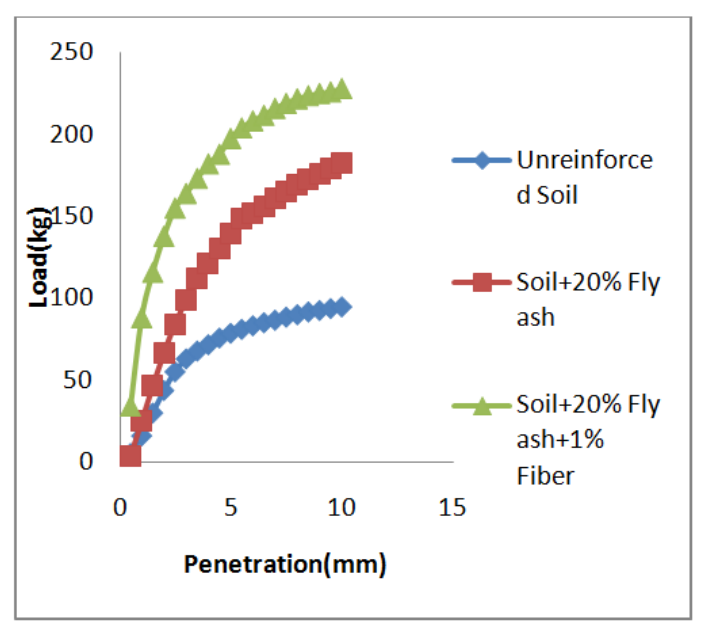

Figure 8: Comparison of CBR Graphs (Variation of Load with Penetration)

\section{CONCLUSIONS}

From the series of tests performed the following conclusions were drawn

- Addition of fly ash and fiber to soil can be used for improving the strength of the sub grade.

- By adding the fly ash to soil in varying percentages, the MDD of the sample initially increases and then start decreasing. The Maximum dry density was found to be $1.68 \mathrm{~g} / \mathrm{cc}$ for $80 \%$ soil and $20 \%$ fly ash proportion.

- By adding the fly ash to soil in varying percentages, the CBR value of the sample initially increases and then starts decreasing. The Maximum CBR was found to be 6.77 for $80 \%$ soil and $20 \%$ fly ash proportion

- From the results it can be observed that the mixture of $80 \%$ soil and $20 \%$ fly ash is the best proportion having maximum dry density and maximum CBR value.

- $\quad$ Based upon the study it can be concluded that the addition of fibers to had a great influence on the engineering behavior of soil- fly ash mixture. 
Fly Ash and Discrete Fibre

- On addition of fiber to soil with $20 \%$ fly ash mixture in varying percentages, the Maximum dry density initially increases and then reduces, the maximum dry density was found to be $1.72 \mathrm{~g} / \mathrm{cc}$ for $1.0 \%$ fiber.

- On addition of fiber to soil with $20 \%$ fly ash mixture in varying percentages, the CBR value initially increases and then reduces, the maximum CBR value was found to be 11.33 for $1.0 \%$ fiber.

- $\quad$ Based upon the results it can be concluded that the sample containing $80 \%$ soil, $20 \%$ fly ash and $1.0 \%$ fiber is the best combination and can be used for road constructions and embankments.

- The maximum CBR obtained for reinforced soil is 11.33. The strength of soil increased and theCBR values of the reinforced increased by 4 times when compared to unreinforced. The local soil reinforced with flyash and fiber can be used for laying roads and embankments.

\section{REFERENCES}

1. Kollu. Prabhakar. Koppula. Ramakrishna Reddy. Strength Characteristics of Coir Fibers and Fly ash on Soil, IJESC Volume 6 Issue No.10 IJESC,2016, pp-2961-2969 pp-2961-2969

2. Sowmya Ratna. P., Prasad. D. S. V., Prasada Raju. G. V. R. Performance of Recron-3s Fiber with Lime in Expansive Soil Stabilization, IOSR Journal of Mechanical and Civil Engineering, e-ISSN: 2278-1684, p-ISSN: 2320-334X, Volume 13, Issue 6 Ver. VI,2016, PP 74-79

3. Mamta Mishra, Maheshwari. U. K., and Saxena. N. K. Improving Strength of Soil using Fiber and Fly ash -A Review, International Research Journal of Engineering and Technology (IRJET), e-ISSN: 2395 -0056 www.irjet.net p-ISSN: 23950072, Volume: 03, Issue: 10,2016, PP 1262-1266

4. Pooja Upadhyay, Kshama Singh. Soil stabilization with fly ash and coir fiber, International Journal for Research in Engineering Application \& Management (IJREAM) ISSN: 2454-9150 Vol-04, Issue-03, 2018, PP 164-169.

5. Tawiah, B. E. N. J. A. M. I. N., \& Asinyo, B. (2016). Advances in spun-dyeing of regenerated cellulose fibers. BEST: International Journal of Management, Information Technology and Engineering, 4, 65-80.

6. Kuldeep Singh Chouhan, Rajesh Jain. Effect of FlyAsh and Fibre on Index Properties of Black Cotton Soil, International Journal of Science Technology \& Engineering (IJSTE) ISSN (online): 2349-784X Volume 2, Issue 01, 2015, PP 43-46

7. Mir Aamir Fayaz, Rajat Balyan, Pooja Sharma. Laboratory Investigation For Stabilization Of Clayey Soil In Kashmir Valley, International Journal of Engineering Development and Research (IJEDR) ISSN: 2321-9939 Volume 6, Issue 3, 2018, PP 3035.

8. Ishfaq Ahmad Lone, Abhishek bawa. Utilization of Fly-Ash and coir fibre in soil reinforcement, A Review, International Journal of Engineering Development and Research (IJEDR) ISSN: 2321-9939 Volume 6, Issue 1,2018, PP 488-489.

9. Ishfaq Ahmad Lone, Abhishek bawa. Utilization of fly-ash and coir fibre in soil reinforcement, International Journal of Civil Engineering and Technology (IJCIET) ISSN Print: 0976-6308 and ISSN Online: 0976-6316 Volume 9, Issue 8, 2018, PP 341346.

10. Carlos Valdés Hernández, R., Arcos Vega, J. L., Fernando Navarro, F., \& Flores Frias, S. (2017). Client's Satisfaction with Software Development Quality in Small and Medium Companies (PYMES) in Baja California, Mexico. International Journal of Computer Science and Engineering (IJCSE), 6(6), 1-8. 
11. Akshaya Kumar Sabat, Abinash Pradhan. Fiber reinforced-fly ash stabilized expansive soil mixes as subgrade material in flexible pavement, Article in Electronic Journal of Geotechnical Engineering, 2014, PP 5757-2768.

12. Hanumantha rao CH. V, Suresh kumar B. V. Enhancement of CBR of Weak Soil Using Flyash And Cement as Admixtures, International Journal of Engineering Research and Development e-ISSN: 2278-067X, p-ISSN: 2278-800X Vol. 12, Issue 1, 2016, PP 40-46

13. Sachin, Mujeeb, Sullia, Dr. Sowmya N. Effect of Coconut Coir Fibres on Black Cotton Soil Blended with Fly Ash, International Journal of Engineering Research \& Technology (IJERT), ISSN: 2278-018, Vol. 5 Issue 10,2016, PP 505-508

14. Tashenova, Z., Sagindykov, K., Omarkhanova, D., Uzakkyzy, N., Kudaykulov, A., \& Nurlybaeva, E. (2016). Algorithm for calculation of parameters of the bearing elements of oil heating installations. International Journal of Chemical Sciences, 14(1), 355-362.

15. Chore. H. S, Kumthe. A. A, Abnave. S. B, Shinde S. S, Dhole. S. S and Kamerkar. S. G. Performance evaluation of polypropylene fibers on sand-fly ash mixtures in highways, Journal of Civil Engineering , 39 (1) (2011) 91-102

16. Razvi. S. S, Medha Jogdande, Rupali Borde, Jadhav Monali, Pathan Aamer Khan, Shaikh Muktar. Stabilization of Soil by Fiber with Fly-Ash, International Journal of Innovative Research in Science Engineering and Technology (IJIRSET), Vol. 6, Issue 5, 2017, PP 9444-6448

17. Swati Sucharita Rout, Monoswi Manini Sahoo and Rupashree Ragini Sahoo. Influences of fly ash and coir fiber on strength properties of soft soil, Research Journal of Engineering Sciences, Vol. 6(10), 2017, PP 1-9

18. Avinash Bhardwaj, Walia. B. S., Influence of Cement and Polyester Fibres on Compaction and CBR Value of Clayey Soil, Indian Geotechnical Conference, 2017

19. Sharma. R. K. Subgrade Characteristics of Locally AvailableSoil Mixed With Fly Ash and Randomly Distributed Fibers, International Conference on Chemical, Ecology and Environmental Sciences (ICEES), 2012, PP 177-181

20. Dr. Arora. K. R. Soil Mechanics and Foundation Engineering, $7^{\text {th }}$ Edition, Standard Publishers Distributors, 2007.

21. Venkatramaiah. C, Geotechnical Engineering, $3^{\text {rd }}$ Edition, New Age International Publishers, 2007. 